\title{
Analisis Kebijakan Luar Negeri Australia Di Era Pemerintahan PM Tony Abbott
}

\author{
Ismail Adi Santoso \\ UIN Syarif Hidayatullah Jakarta \\ ismailadisant@gmail.com
}

\begin{abstract}
ABSTRAK
Setiap negara pasti memiliki arah dan tujuan negaranya. Untuk mencapai tujuan tertentu dibutuhkan sebuah kebijakan luar negeri. Sebagai sebuah negara Australia tentu memiliki tujuan dan kepentingan nasionalnya. Pada era pemerintahan Perdana Menteri Tony Abbott, Australia memiliki kebijakan luar negeri yang ditujukan untuk memenuhi kepentingan nasionalnya. Isu-isu ekonomi dan imigran merupakan isu yang menjadi pokok utama dalam pemerintahan Tony Abbott. Dalam meningkatkan perekonomian, Australia menjalin kerja sama dalam bentuk free trade agreement dengan Tiongkok dan Korea Selatan. Australia menerapkan kebijakan pencegahan imigran ilegal yang dinamai Operation Sovereign Borders yang dilakukan untuk mencegah imigran ilegal masuk ke dalam teritorial Australia.
\end{abstract}

Kata Kunci: Kebijakan Luar Negeri, Australia, Free Trade Agreement, Operation Sovereign Borders

\begin{abstract}
Every nation must have directions and objectives. To achieve certain objectives requires foreign policies. As a nation, Australia certainly has its own national goals and interests. In Tony Abbott's government era, Australia had many foreign policies aimed at fulfilling its national interests. Economic and immigrant issues are the focus in Abbott's government. Australia cooperates in the form of free trade agreements with China and Korea to improve its economy. Australia also implements an illegal immigrant prevention policy called Operation Sovereign Borders which is conducted to prevent illegal immigrants from entering Australian territory.
\end{abstract}

Keywords: Foreign Policy, Australia, Free Trade Agreement, Operation Sovereign Borders

\section{Pendahuluan}

Setiap negara hampir pasti membutuhkan interaksi dengan negara lain dalam rangka untuk mencapai tujuan dan memenuhi kepentingan negaranya (AS, 2018) Negara melakukan interaksi dengan negara-negara lain, atau bahkan organisasi non-negara di dalam bingkai kebijakan luar negeri. Kebijakan luar negeri didesain untuk memenuhi kepentingan nasional 
baik dalam hal keamanan, tujuan ideologis, maupun kemakmuran masyarakatnya. Kebijakan luar negeri merupakan visi atau set of interests dalam berinteraksi dengan negara/aktor lain, strategi dan ide yang digunakan untuk mencapai tujuan sebuah negara. Dalam penetapan kebijakan luar negeri (decision-making) suatu negara dipengaruhi oleh dua faktor penentu, yaitu internasional atau eksternal, dan domestik atau internal (AS, 2018). Kedua faktor tersebut merupakan hal yang menentukan terbentuknya kebijakan luar negeri suatu negara. Australia, sebagai sebuah negara sudah tentu juga mempunyai kebijakan luar negerinya. Kebijakan luar negeri suatu negara sangat besar kemungkinan dipengaruhi oleh figur pemimpinnya. Di era Tony Abbott sebagai Perdana Menteri, banyak agenda yang menjadi fokus utama seperti suaka, perubahan iklim, maupun bantuan kemanusiaan (McDonald, 2015).

Kebijakan luar negeri Australia cukup menonjol di tahun 2014. Di tahun itu, Australia menjadi tuan rumah pertemuan negara-negara Kelompok Dua Puluh (G20) di bulan November. Di sisi lain, Australia juga sedang menjabat sebagai Presiden Dewan Keamanan Perserikatan Bangsa-Bangsa (PBB). Peran Australia di internasional juga cukup meningkat. Pada bulan Juli, pemerintah Australia merespons serangan terhadap pesawat MH17 di Ukraina dengan memanfaatkan posisi mereka di Dewan Keamanan PBB untuk mengutuk serangan tersebut dan mendorong pelaksanaan investigasi internasional. Australia juga muncul sebagai anggota utama dalam koalisi bersama untuk melawan Negara Islam Irak Suriah (ISIS) yang dipimpin oleh Amerika Serikat, juga dengan memanfaatkan posisi di Dewan Keamanan, melalui Menteri Luar Negeri Julie Bishop, untuk mendorong aksi internasional yang lebih kuat untuk merespon ancaman teroris dan foreign fighters (McDonald, 2015).

Sebagaimana yang diargumentasikan oleh Matt McDonald, bahwa pertimbangan domestik yang populis memegang peran kunci dalam membentuk kebijakan luar negeri Australia di bawah kepemimpinan Tony Abbott (Simpson, 2015). Pemerintah Australia cenderung mengutamakan pertimbangan politik dalam negeri, khususnya opini publik, untuk urusan terhadap dunia luar (McDonald, 2015). Kebijakan-kebijakan tersebut dapat dilihat pada isu-isu seperti suaka, iklim, bantuan-bantuan kepada negara lain, bahkan terhadap hubungan bilateral dengan Indonesia. Di era kepemimpinannnya, pemerintah Australia menaruh perhatian besar terhadap isu-isu seperti yang berkaitan dengan pencari suaka dan mengaitkannya dengan 
isu keamanan perbatasan dan isu ancaman teror lintas negara dan kembalinya komitmen tentara Irak untuk memberantas ISIS (Simpson, 2015). Dalam merespons peristiwa serangan terhadap pesawat MH17 dan ancaman oleh PM Tony Abbott kepada Vladimir Putin pada sebuah event di pertemuan G20 pun menunjukkan bahwa kebijakan-kebijakan luar negeri pada akhirnya dilihat melalui sudut pandang politik domestik. Tren tersebut juga terjadi hingga awal tahun 2015 di mana penetapan Anggaran Federal (Federal Budget) pada bulai Mei dan tanggapan Australia atas eksekusi warganya yang menyelundupkan narkotika di Indonesia pada bulan April, menampakkan kecenderungan untuk melihat kebijakan luar negerinya dengan pertimbangan politik dalam negeri.

\section{Teori}

\subsection{Kepentingan Nasional}

Konsep kepentingan nasional merupakan hal yang penting untuk memahami dan menjelaskan perilaku internasional (Husna, 2012: 6). Kepentingan nasional adalah keseluruhan nilai-nilai yang meliputi aspek ekonomi, politik, dan sosial yang dimiliki oleh suatu negara (Hamzah, 2015: 8). Lebih lanjut, kepentingan nasional merupakan tujuan mendasar dan dijadikan sebagai acuan untuk menentukan suatu kebijakan di suatu negara. Kepentingan nasional juga menjadi unsur yang vital bagi sebuah negara karena menjadi tujuan utama dan menjadi panduan bagi para pembuat kebijakan dalam merumuskan kebijakan luar negeri negaranya. Kepentingan nasional merupakan tujuan dan ambisi dari negara, baik dalam bidang ekonomi, militer, atau budaya. Hans J. Morgenthau menyampaikan tentang kepentingan nasional yaitu, the concept of the national interest, then, contains two elements, one that is logically required and in that sense necessary, and one that is variable and determined by circumstances (Husna, 2012: 7). Dari pendapat Morgenthau dapat dikatakan bahwa kepentingan nasional terdiri dari dua unsur, yakni ditentukan oleh pemenuhan kebutuhan dalam negeri itu sendiri dan mempertimbangkan keadaan sekitar atau keadaan luar negerinya (Husna, 2012).

Pengertian kepentingan nasional tidak hanya dikemukakan oleh Hans J. Morgenthau saja. Banyak pakar-pakar hubungan internasional lain yang mengemukakannya, di antaranya adalah Charles Kegley dan Eugene Wittkopf. Mereka berpendapat bahwa 
kepentingan nasional adalah upaya suatu negara dalam memberikan rasa aman kepada warga negaranya, baik dari serangan luar maupun dalam negerinya sendiri, kesejahteraan rakyatnya dan melindungi nilai-nilai negaranya. Kepentingan nasional yang sudah ditetapkan menjadi tujuan sebuah negara harus diaplikasikan melalui sebuah kebijakan luar negeri (Husna, 2012).

Dengan demikian, kepentingan nasional sangat berhubungan erat dengan kebijakan luar negeri suatu negara, karena melalui kebijakan luar negeri, upaya suatu negara untuk memberi rasa aman dan kesejahteraan terhadap warga negaranya dapat dipenuhi. Dalam mewujudkan kepentingan nasional, suatu negara berusaha untuk melindungi dan mempertahankan negaranya dari pihak yang dapat mengancam pemenuhan kebutuhan suaau negara. Kepentingan nasional membutuhkan suatu kebijakan luar negeri agar tujuan dari sebuah negara dapat direalisasikan. Lebih lanjut, kebijakan luar negeri dapat dikatakan sebagai perpanjangan tangan dari kepentingan nasional (Husna, 2012).

\subsection{Kebijakan Luar Negeri}

Demi merealisasikan kepentingan nasionalnya, suatu negara perlu untuk menentukan kebijakan luar negeri. Penerapan kebijakan tersebut harus memenuhi kepentingan seluruh masyarakat dan kepentingan nasional. Menurut Rosenau, kebijakan luar negeri adalah seperangkat rencana dan komitmen yang menjadi pedoman bagi perilaku pemerintah dalam berhubungan dengan aktor-aktor lain di lingkungan eksternal yang bertujuan untuk mempertahankan kelangsungan hidup suatu negara (Hamzah, 2015). Istilah kebijakan luar negeri didefinisikan dengan berbagai macam oleh para ahli. Kebanyakan dari para ahli meyakini bahwa kebijakan luar negeri berkaitan dengan perilaku negara terhadap negara lain (AS, 2018:1).

Kebijakan luar negeri suatu negara dapat dipengaruhi oleh dua faktor utama, yakni internasional atau eksternal, dan domestik atau internal. Faktor-faktor tersebut merupakan unsur yang membentuk sebuah kebijakan luar negeri. Namun, tingkat pengaruh dari faktor internal dan eksternal terhadap kebijakan luar negeri suatu negara bisa berbeda, tergantung negara dan kondisi politik di negara tersebut (AS, 2018). Faktor eksternal yang memengaruhi kebijakan luar negeri terdiri dari: pertama, sistem internasional; kedua, 
hukum internasional; ketiga, organisasi internasional; keempat, aliansi; dan kelima, strategi/persaingan militer. Di sisi lain, faktor internal adalah kondisi yang berasal dari suatu negara, seperti: budaya dan sejarah; geografi, populasi, dan luas wilayah; pertumbuhan ekonomi dan sumber daya alam; kemampuan militer; sistem politik; karakter pemimpin negara; partai politik dan kelompok kepentingan; pers dan opini publik, dan; sains dan teknologi (AS, 2018). Faktor internal tadi dapat dikatakan sebagai karakteristik umum dari sebuah negara. Perbedaan yang terdapat di masing-masing negara, terutama pada faktor-faktor tersebut sudah jelas sangat memengaruhi proses perumusan kebijakan luar negeri di suatu negara. Lebih lanjut, faktor internal dan ekstermal yang sebelumnya disebutkan, tidak akan pernah terlepas dari perumusan kebijakan yang dilakukan oleh suatu negara.

\section{Tinjauan Pustaka}

Literatur yang membahas mengenai kebijakan luar negeri yang diterapkan Australia, baik dari segi bidangnya maupun periodenya. Adapun literatur yang ingin dijadikan tinjauan pustaka pertama dalam penelitian ini adalah penelitian berjudul Kebijakan Unilateral Penanganan Imigran Ilegal Australia Pasca Pemilihan Umum Australia Tahun 2013. Fakhrul Rizal Razak (2018) mengungkapkan bagaimana Australia mengambil kebijakan militer dalam menanggulangi isu imigran ilegal yang datang ke negaranya setelah pemilu Australia tahun 2013. Penelitian ini mengemukakan bahwa sekuritisasi yang dilakukan sejak masa kampanye pemilihan umum hingga pemerintahan Perdana Menteri Tony Abbott ditujukan untuk mengangkat isu imigran ilegal dalam agenda keamanan nasional karena isu ini dianggap darurat dan sebagai legitimasi atas diambilnya tindakan luar biasa melalui Operation Sovereign Borders untuk mengeliminasi ancaman melalui kedatangan imigran ilegal ke dalam negara Australia (Razak, 2018).

Penelitian kedua yang dijadikan rujukan adalah penelitian berjudul Australian Foreign Policy under the Abbott Government: Foreign Policy as Domestic Politics?. Penelitian ini membahas mengenai kebijakan luar negeri Australia di bawah kepemimpinan Perdana Menteri Tony Abbott yang cenderung dipengaruhi oleh politik dalam negerinya, terutama dengan opini publik, untuk menghadapi dunia luar. Penelitian ini menjelaskan bahwa hal tersebut dapat 
dilihat dari beberapa isu seperti pencari suaka, perubahan iklim dan bantuan kemanusiaan, dan isu tradisional seperti hubungan bilateral dengan Indonesia serta isu keamanan internasional (McDonald, 2015).

\section{Pembahasan}

\subsection{Pemerintahan Tony Abbott}

Pemerintahan Tony Abbott merupakan pemerintahan federal Australia yang diketuai oleh Tony Abbott sebagai Perdana Menteri ke-28. Pemerintahan ini dibentuk oleh koalisi Partai Liberal dan Nasional atau dikenal dengan The Coalition. Tony Abbott berasal dari Partai Liberal, sedangkan pihak dari Partai Nasional mengisi kursi Wakil Perdana Menteri. Pemerintahan Tony Abbott sah berkuasa setelah dilantik oleh Gubernur Jenderal Australia, Dame Quentin Bryce, pada 18 September 2013 di Government House, kediaman Gubernur Jenderal Australia. Pemerintahan ini menggantikan pemerintahan yang dibentuk oleh koalisi Partai Buruh Australia (ALP) yang sudah memimpin sejak 2007 di bawah kepimpinan Kevin Rudd dan Julia Gillard. Abbott dilantik bersama 18 menteri kabinet, 11 menteri, dan 12 parliamentary secretaries atau dapat disebut juga sebagai assistant minister (News.com.au, 2013).

Dalam kampanyenya untuk menuju pemilihan umum Australia di tahun 2013, Tony Abbott menyampaikan bahwa dalam tiga tahun pemerintahan, koalisinya akan melakukan kebijakan-kebijakan yang membawa Australia ke arah yang lebih baik. Beberapa dari kebijakan tersebut adalah memperkuat ekonomi, menciptakan lapangan kerja baru. Satu yang menjadi sorotan khususnya bagi masyarakat Australia adalah kebijakan mencegah imigran gelap masuk ke Australia melalui slogan 'turn back the boat'. Selain itu, koalisi Abbott juga mendorong pembangunan infrastruktur demi menyokong ekonomi Australia.

Di masa pemerintahannya, Abbott dan koalisinya berupaya untuk merealisasikan janji-janji kampanyenya. Dalam tiga tahun pemerintahan, banyak kebijakan-kebijakan yang diambil. Australia menandatangani beberapa kesepakatan perdagangan bebas dengan negara-negara seperti Tiongkok dan Korea Selatan.. Kesepakatan dengan Tiongkok atau yang dikenali dengan China-Australia Free Trade Agreement (ChAFTA) telah disepakati pada tahun 2015. ChAFTA pada khususnya mengatur tentang penghapusan/pengurangan 
tarif dan kuota perdagangan untuk banyak komoditas agrikultur seperti daging, olahan susu, makanan laut hingga produk energi serta manufaktur. Kesepakatan tersebut juga memungkinkan terbukanya kesempatan investasi bagi kedua negara. Dengan tercapainya kesepakatan tersebut, pemerintahan Abbott meyakini bahwa ChAFTA akan membawa keuntungan besar bagi perekonomian Australia serta meningkatkan lapangan kerja (Conifer, 2015).

Kemudian, pemerintahan Abbott juga menyelesaikan kesepakatan perdagangan bebas dengan Korea Selatan. Kesepakatan yang dinamai Korea-Australia Free Trade Agreement (KAFTA). Negosiasi menuju FTA antara Korea dan Australia dimulai sejak Juni 2009 dan dapat disepakati setelah lima tahun, yakni pada Desember 2013. KAFTA membuka kesempatan bagi produk agrikultur ekspor utama Australia seperti daging, gandum, gula, olahan susu, wine, makanan laut, serta sumber daya, energi dan barang manufaktur seiring dihapuskannya tarif yang mencapai 300\%. Sebaliknya, Korea Selatan mendapat keuntungan bagi industri otomotifnya. Australia menyetujui untuk mencabut tarif bagi beberapa produk mobil Korea Selatan (Liou, 2016).

Dalam hal pencegahan imigran gelap masuk ke Australia, pemerintahan Abbott menerapkan kebijakan yang diberi nama Operation Sovereign Borders (OSB). OSB merupakan operasi penjagaan perbatasan yang dilakukan oleh militer dengan didukung oleh beberapa lembaga pemerintahan federal Australia. OSB mencegah masuknya orang yang melakukan perjalanan secara ilegal menggunakan perahu dengan mencegatnya dan mengeluarkannya dari perairan Australia untuk kemudian di proses di luar Australia. Kebijakan tersebut berlaku untuk semua orang, termasuk anak-anak. Mereka yang datang dengan menggunakan perahu secara ilegal akan dikembalikan ke negara tempat mereka bertolak atau ditempatkan di pusat detensi yang berada di Papua Nugini atau Nauru. (Ardianti, 2015).

\subsection{Free Trade Agreement}

Free Trade Agreement (FTA) adalah kesepakatan/perjanjian internasional yang mengatur pengurangan atau penghapusan batasan/hambatan perdagangan barang dan jasa, serta investasi (DFAT, n.d.). FTA memungkinkan terciptanya hubungan perdagangan dan 
komersial yang kuat dan dapat berkontribusi pada perluasan kerja sama dan integrasi ekonomi di antara negara-negara yang berpartisipasi dalam FTA tersebut (Culas \& Timsina, 2019). Pembentukan berbagai FTA adalah bentuk dari liberalisasi perdagangan yang sudah menjadi sebuah keniscayaan dan tidak dapat dihindari oleh setiap negara sebagai anggota komunitas internasional. FTA dapat dibentuk secara bilateral maupun regional.

\subsubsection{China-Australia Free Trade Agreement}

China-Australia Free Trade Agreement (ChAFTA) merupakan salah satu kesepakatan FTA yang dijalankan oleh Australia. ChAFTA mulai berlaku pada 20 Desember 2015 setelah melalui proses panjang negosiasi sebanyak 21 kali yang membahas beberapa isu yang cukup sensitif seperti bea cukai dan kuota produk agrikultur, barang manufaktur, jasa, sampai izin masuk sementara bagi pekerja yang memiliki keterampilan dan investasi luar negeri (Culas \& Timsina, 2019). Tiongkok merupakan mitra dagang terbesar Australia. Seperempat dari keseluruhan jumlah ekspor Australia dibeli oleh Tiongkok. (DFAT, 2018a). Kesepakatan ini tentu memberikan keuntungan kedua negara, khususnya Australia. Jika ChAFTA sudah secara penuh diterapkan, hampir seluruh dari barang ekspor Australia tidak dikenakan biaya untuk masuk ke pasar Tiongkok. Produk agrikultur Australia seperti gandum, daging sapi, produk olahan susu, anggur, dan holtikultur mendapatkan penghapusan tarif. Namun demikian, kebijakan penghapusan tarif untuk berbagai produk Australia diterapkan secara bertahap.

Tiongkok juga merupakan pasar produk energi, sumber daya, dan manufaktur terbesar bagi Australia dengan nilai ekspor lebih dari 85 miliar Dolar Australia di tahun 2017. Pada implementasi penuh ChAFTA, seluruh produk ekspor energi, sumber daya, dan manufaktur seperti bijih besi, gas alam, batubara, tembaga, alumunium, nikel, hingga produk medis seperti obat dan vitamin serta suku cadang mobil akan dibebaskan dari biaya masuk ke Tiongkok. Namun, pembebasan bea tersebut akan diterapkan secara bertahap sampai implementasi penuh ChAFTA pada 1 Januari 2029 (DFAT, 2018a) 
Selain itu, Tiongkok juga merupakan pasar jasa terbesar bagi Australia dengan nilai ekspor jasa senilai 15.8 miliar Dolar Australia pada tahun 2017. Melalui ChAFTA, Tiongkok menawarkan akses pasar bagi bank, perusahaan asuransi, sekuritas, badan hukum dan bisnis jasa lainnya seperti jasa konstruksi, kesehatan, manufaktur, dan telekomunikasi milik Australia.

ChAFTA meningkatkan kesempatan bagi para investor dari Australia dan Tiongkok. Komitmen Tiongkok pada investasi di ChAFTA melindungi posisi kompetitif bisnis Australia di Tiongkok di masa depan. Angka bisnis Australia yang masuk ke pasar Tiongkok meningkat. Sektor bank menjadi sektor terbanyak dalam investasi langsung Australia di Tiongkok. Nilai saham investasi Australia di Tiongkok mencapai 77.1 miliar Dolar Australia di akhir 2017. Lebih lanjut, nilai investasi Tiongkok di Australia per 2017 mencapai 65 miliar Dolar. ChAFTA juga mendorong peningkatan investasi Tiongkok di Australia melalui pelonggaran screening bagi investasi asing.

ChAFTA juga mendukung peningkatan perdagangan dan investasi antara Australia dan Tiongkok dengan mengurangi hambatan mobilitas tenaga kerja dan meningkatkan akses masuk sementara dalam konteks kerangka kerja dan perlindungan imigrasi dan ketenagakerjaan.

\subsubsection{Korea-Australia Free Trade Agreement}

Korea-Australia Free Trade Agreement (KAFTA) adalah kesepakatan lainnya yang dilakukan oleh Australia. Bersama Korea Selatan, negosiasi kesepakatan ini dimulai pada Juni 2009. Negosiasi tersebut dimulai di masa pemerintahan Kevin Rudd, namun baru dapat mencapai kesepakatan di masa pemerintahan Tony Abbott pada Desember 2013 (Liou, 2016). KAFTA yang mulai berlaku pada Desember 2014 ini, secara substansi mengatur tentang liberalisasi perdagangan antara Australia dan Korea Selatan. KAFTA membuka akses yang besar bagi perdagangan Australia untuk bisa masuk ke pasar Korea Selatan.

Kesepakatan perdagangan ini membuka kesempatan bagi 99 persen barang ekspor Australia untuk dapat masuk ke Korea Selatan tanpa dikenakan biaya atau 
syarat apapun. Produk seperti daging sapi, gula mentah, gandum, olahan susu, anggur botolan, dan produk holtikultura lainnya akan mendapatkan pemotongan bea masuk. Namun demikian, penerapan pemotongan bea tersebut ada yang berlaku saat KAFTA berlaku, seperti untuk gula mentah dan hortikultura, dan ada yang berlaku secara bertahap, seperti untuk daging sapi. Korea menghapus 40 persen bea masuk produk daging sapi Australia per 1 Januari 2028. Demikian pula dengan produk olahan susu (keju, mentega, susu formula untuk bayi) yang dihapus bea masuknya. Penghapusan bea untuk produk olahan susu lainnya akan berlaku per 1 Januari 2033. 88 persen produk energi, sumber daya, dan manufaktur Australia juga mendapat bebas bea masuk pasar Korea Selatan terhitung sejak KAFTA berlaku, dengan sisanya akan dibebaskan dari bea masuk per 1 Januari 2023. Penghapusan bea berlaku bagi produk utama seperti gas alam cair, alumunium, suku cadang otomotif, dan produk farmasi Australia.

KAFTA juga membebaskan akses bagi beragam perusahaan sektor jasa Australia seperti jasa hukum, keuangan, akuntasi, dan telekomunikasi. Firma hukum asal Australia diperkenankan membuka kantor di Korea Selatan dan bekerja sama dengan firma hukum lokal serta merekrut pengacara lokal. Untuk tenaga akuntan Australia dibolehkan untuk membuka kantor untuk konsultasi akuntasi dan dibolehkan untuk bekerja atau berinvestasi di kantor akuntan lokal. Bidang-bidang lain seperti pendidikan atau teknik juga mendapat jaminan akses masuk ke pasar Korea Selatan (DFAT, 2018c)

Bagi investor, KAFTA membuka peluang yang lebih luas bagi investasi Australia ke Korea Selatan dan juga mendorong investasi langsung Korea Selatan di Australia. Di bawah KAFTA, Korea membuka pintu bagi investasi Australia dengan menghapus hambatan akses pasar di sektor-sektor utama seperti telekomunikasi, layanan hukum serta akuntansi dan perpajakan. KAFTA juga memberi peningkatan proteksi dan kepastian bagi investasi kedua negara dengan ketentuan untuk memastikan non-diskriminasi dan perlindungan serta keamanan untuk investasi. KAFTA juga menyediakan mekanisme perselisihan antara investor 
dengan negara atau Investor-State Dispute Settlement (ISDS) untuk penegakan komitmen yang sudah ditetapkan (DFAT, 2018b).

\subsubsection{Operation Sovereign Borders}

Operasi Kedaulatan Perbatasan atau Operation Sovereign Borders (OSB) merupakan operasi pengamanan keamanan perbatasan yang diluncurkan oleh Australia pada 18 September 2013. Operasi ini dijalankan oleh militer Australia dengan dibantu oleh unsur-unsur pemerintahan federal. Operasi tersebut dijalankan sebagai bentuk respons untuk memerangi penyelundupan manusia dan melindungi perbatasan Australia serta mencegah orang-orang yang membahayakan nyawa mereka di lautan (Ardianti, 2015).

Untuk menjalankan OSB dibentuk sebuah gugus tugas yang dinamai Joint Agency Taskforce. Gugus tugas tersebut terdiri dari beberapa Lembaga yang menjalani fungsinya masing-masing. Joint Agency Taskforce dibentuk sebagai upaya pemerintah Australia untuk memerangi penyelundupan manusia dan melindungi perbatasan. Joint Agency Taskforce terdiri dari tiga kelompok tugas operasi, yaitu:

1) Disruption and Deterrence Task Group, yang dipimpin oleh Kepolisian Federal;

2) Detection, Interception and Transfer Task Group, yang dipimpin oleh Komando Perlindungan Perbatasan; dan

3) Offshore Detention and Return Task Group, yang dipimpin oleh Departemen Imigrasi dan Kependudukan.

OSB diketuai oleh seorang komandan militer senior bintang 3. Komandan OSB direkomendasikan oleh Panglima Angkatan Bersenjata Australia yang sekaligus sebagai contoh kontrol dan perintah untuk pelaksanaan operasi tersebut. Komandan OSB kemudian bertanggung jawab langsung terhadap Menteri Imigrasi sebagai penanggung jawab terhadap OSB. OSB di awal pembentukannya dikepalai 
oleh Letnan Jenderal Angus Campbell yang ditunjuk pada 19 September 2013 (Ardianti, 2015).

Operasi tersebut dijalankan dengan tujuan untuk mengamankan perbatasan dan menyetop laju perahu yang membawa imigran ilegal untuk masuk ke Australia. Dengan adanya kebijakan ini, orang-orang yang melakukan perjalanan ke Australia secara illegal menggunakan perahu akan dicegat dan dikeluarkan dari perairan Australia dan dikembalikan ke tempat di mana mereka bertolak. Orang-orang tersebut tidak akan pernah dapat memilih untuk diproses dan dimukimkan di Australia. Kebijakan pengembalian tersebut berlaku untuk semua orang (keluarga, anak-anak, orang dengan keahlian, dan anak-anak tanpa pendamping) tanpa ada pengecualian. Selain dikembalikan ke tempat di mana mereka berangkat, orangorang tersebut juga dapat ditempatkan di pusat pemrosesan di Papua Nugini atau Nauru (Ardianti, 2015)

OSB merupakan operasi penegakan hukum sipil yang mengadopsi struktur militer untuk mencegah kedatangan perahu-perahu ilegal. Operasi ini merupaka inisiatif pemerintah Australia di bawah kepemimpinan Tony Abbott untuk melindungi perbatasan negara dari orang-orang yang ini menyelundup masuk ke Australia. OSB dibuat dengan beberapa alasan, antara lain sebagai bentuk penanggulangan kejahatan lintas negara dan besarnya biaya penanganan pengungsi, serta untuk melindungi perbatasan Australia.

Di samping OSB, pemerintahan Australia di bawah Tony Abbott juga memberlakukan kembali Temporary Protection Visa (TPV) atau Visa Perlindungan Sementara. TPV dikhususkan untuk para pengungsi yang sudah masuk ke Australia. Mereka yang mendapatkan TPV dapat bebas dari penahanan. Namun, mereka yang mendapat TPV tidak akan bisa mendapatkan status permanent resident (Ardianti, 2015).

\section{Kesimpulan}

Pada tahun 2013, kubu Liberal-Nasional atau familiar dengan sebutan The Coalition berhasil memenangkan pemilihan umum Australia, mengalahkan kubu ALP yang telah 
berkuasa sejak 2007. Seiring dengan kemenangan kubu tersebut, Tony Abbott yang merupakan ketua dari koalisi tersebut diangkat menjadi Perdana Menteri Australia ke-28. Di masa kampanye, Abbott dan The Coalition menjanjikan perubahan yang besar dan dapat membawa Australia ke arah yang lebih baik dalam tiga tahun pemerintahan melalui kebijakan-kebijakan yang mendukung penguatan ekonomi dan penciptaan lapangan kerja baru. Pemerintahan Abbott juga menjanjikan kebijakan yang mencegah imigran ilegal untuk masuk ke Australia.

Janji perubahan tersebut kemudian satu per satu mulai direalisasikan. Demi mendorong penguatan ekonomi, Pemerintahan Tony Abbott menyepakati kesepakatan perdagangan bebas atau free trade agreement (FTA) dengan Tiongkok atau dikenal dengan China-Australia Free Trade Agreement (ChAFTA). FTA tersebut mulai berlaku pada Desember 2015. ChAFTA mengatur banyak kesepakatan baik dalam bidang ekspor dan impor barang dan jasa hingga investasi, ChAFTA mempermudah akses bagi produk ekspor Australia untuk masuk ke pasar Tiongkok melalui pengurangan atau penghapusan bea masuk. ChAFTA juga mempermudah bisnis sektor jasa Australia seperti bank, hukum hingga jasa konstruksi untuk melakukan ekspansi ke pasar Tiongkok. Selain itu, ChAFTA juga membuka peluang investasi yang lebih luas bagi ke dua negara melalui permudahan perizinan tenaga kerja asing.

Selain kesepakatan FTA dengan Tiongkok, Australia juga menyepakati FTA bersama Korea Selatan. Kesepakatan tersebut dikenal dengan Korea-Australia Free Trade Agreement (KAFTA). FTA tersebut mulai diberlakukan pada Desember 2013. KAFTA memperluas akses barang dan jasa Australia untuk masuk ke pasar Korea Selatan. Hampir seluruh barang Australia terbebas dari bea masuk pasar Korea Selatan. Selain itu, sektor jasa Australia seperti firma hukum dan akuntansi diperkenankan membuka kantor dan pelayanan serta berinvestasi di Korea Selatan. KAFTA juga membuka peluang bagi investor kedua negara untuk berinvestasi. Korea Selatan menghilangkan hambatan-hambatan investasi di sektor utama seperti jasa hukum, akuntasi, perpajakan dan telekomunikasi. Perlindungan dan jaminan terhadap investasi juga diberikan bagi Australia. Investor juga diberikan kewenangan untuk menyelesaikan perselisihan jika terjadi sengketa melalui mekanisme Investor-State Dispute Settlement (ISDS).

Kebijakan lainnya yang dilaksanakan adalah Operation Sovereign Borders (OSB). OSB merupakan kebijakan pemberantasan imigran ilegal yang dilakukan secara militer. Kebijakan 
ini dijalankan dengan mencegah kapal yang membawa orang-orang secara ilegal untuk masuk ke perairan Australia dan mengembalikannya ke tempat di mana mereka bertolak atau orangorang tersebut akan ditempatkan di pusat pemrosesan di Papua Nugini atau Nauru. Imigranimigran tersebut tidak akan dapat memilih untuk diproses atau bahkan diterima di Australia. Kebijakan tersebut pun berlaku bagi semua orang tanpa melihat usia, jenis kelamin, maupun keahlian yang dimilikinya. Penerapan OSB bertujuan untuk melindungi perbatasan Australia dan atas dasar penghematan biaya pengurusan imigran yang dianggap cukup tinggi. OSB dilakukan oleh militer dengan bantuan dari berbagai lembaga pemerintahan federal Australia, dengan dikepalai oleh seorang perwira militer senior berbintang 3. Untuk pelaksanaannya, dibentuk sebuah gugus tugas bernama Joint Agency Taskforce yang terdiri dari beberapa lembaga pemerintahan seperti Kepolisian Federal dan Border Force serta lembaga lain dengan tupoksinya masing-masing. Bagi imigran yang sudah telanjur masuk ke Australia akan diberikan visa perlindungan yang berlaku untuk sementara waktu. Visa tersebut membebaskan dia dari pemrosesan keimigrasian. Namun, pemilik visa tersebut tidak akan pernah bisa mendapatkan status residen tetap Australia

\section{DAFTAR PUSTAKA}

Ardianti. (2015). Kebijakan Australia Dalam Menangani Imigran Ilegal di Bawah Kepemimpinan Perdana Menteri Tony Abbott Tahun 2013. JOM FISIP, 2(2). https://doi.org/10.1017/CBO9781107415324.004

AS, B. (2018). The Study of Foreign Policy in International Relations. Journal of Political Sciences \& Public Affairs, 06(04). https://doi.org/10.4172/2332-0761.1000337

Conifer, D. (ABC N. (2015). Print Email Facebook Twitter More Australia and China sign "history making" free trade agreement after a decade of negotiations. Retrieved April 7, 2020, from https://www.abc.net.au/news/2015-06-17/australia-and-china-sign-free-tradeagreement $/ 6552940$

Crowley, K. (2017). Up and down with climate politics 2013-2016: the repeal of carbon pricing in Australia. Wiley Interdisciplinary Reviews: Climate Change, 8(3). https://doi.org/10.1002/wcc.458

Culas, R. J., \& Timsina, K. P. (2019). China-Australia Free Trade Agreement: Implications for Australian agriproducts trade and farm economies China-Australia Free Trade Agreement: Implications for Australian agriproducts trade and farm economies. The Australasian Agricultural and Resources Economics Society.

DFAT, A. (n.d.). Australia Free Trade Agreements. Retrieved April 7, 2020, from https://www.dfat.gov.au/trade/agreements/Pages/trade-agreements 
DFAT, A. (2018a). ChAFTA outcomes at a glances. Retrieved from https://www.dfat.gov.au/trade/agreements/in-force/chafta/fact-sheets/Pages/chaftaoutcomes-at-a-glance

DFAT, A. (2018b). KAFTA and investment. Retrieved from https://www.dfat.gov.au/trade/agreements/in-force/kafta/fact-sheets/Pages/kafta-andinvestment

DFAT, A. (2018c). KAFTA outcomes at a glance. Retrieved from https://www.dfat.gov.au/trade/agreements/in-force/kafta/fact-sheets/Pages/kafta-outcomesat-a-glance

Hamzah, P. N. (2015). Bergabungnya Kroasia Menjadi Anggota Uni Eropa. UIN Syarif Hidayatullah Jakarta.

Husna, A. F. (2012). Perubahan Kebijakan Luar Negeri Amerika Serikat dalam Memerangi Terorisme Internasional di Afghanistan Pada Periode Pemerintahan Barack Obama. UIN Syarif Hidayatullah Jakarta.

Liou, T. (2016). An Analysis of FTA-Centered South Korea-Australia Economic Relations. The Journal of Intenational Relations XXXXII, 64-95.

McDonald, M. (2015). Australian Foreign Policy under the Abbott Government: Foreign Policy as Domestic Politics? Australian Journal of International Affairs, 69(6), 651-669. https://doi.org/10.1080/10357718.2015.1056514

News.com.au. (2013). Abbott determined to deliver on promises. Retrieved April 7, 2020, from https://www.news.com.au/national/breaking-news/abbott-springs-into-action-on-dayone/news-story/80be5ceeeb6cadef2e9b68a5129e6d75

Razak, F. R. (2018). Kebijakan Unilateral Penanganan Imigran Ilegal Australia Pasca Pemilihan Umum Asutralia Tahun 2013. Jurnal Politik Internasional, 20(2), 137-159. https://doi.org/10.7454/global.v20i2.332

Simpson, K. (2015). Issues in Australian Foreign Policy. Australian Journal of Politics and History, 61(4), 606-617. 